\title{
Occurrence of Babesia Species and Co-Infection with Hepatozoon canis in Symptomatic Dogs and in Their Ticks in Eastern Romania
}

\author{
Lavinia Ciuca ${ }^{1, *}$, Gabriela Martinescu ${ }^{2, *}$, Liviu Dan Miron ${ }^{2}$, Constantin Roman ${ }^{2} \mathbb{D}$, Dumitru Acatrinei ${ }^{2}$, \\ Giuseppe Cringoli ${ }^{1}$, Laura Rinaldi ${ }^{1}$ and Maria Paola Maurelli ${ }^{1}{ }^{\mathbb{C}}$
}

1 Department of Veterinary Medicine and Animal Production, University of Naples Federico II, CREMOPAR Via Delpino, 1, 80137 Naples, Italy; cringoli@unina.it (G.C.); laura.rinaldi@unina.it (L.R.); mariapaola.maurelli@unina.it (M.P.M.)

2 Parasitology Service, Clinics Department, Faculty of Veterinary Medicine, "Ion Ionescu de la Brad" Iasi University of Life Sciences (IULS), Mihail Sadoveau Alley, 3, 700489 Iasi, Romania; Imiron@uaiasi.ro (L.D.M.); roman.const@yahoo.com (C.R.); dacatrinei@yahoo.com (D.A.)

* Correspondence: lavinia_vet1@yahoo.com (L.C.); martinescugabi11@yahoo.co.uk (G.M.); Tel.: +39-3661381556 (L.C.); +40-757872575 (G.M.)

check for updates

Citation: Ciuca, L.; Martinescu, G.; Miron, L.D.; Roman, C.; Acatrinei, D.; Cringoli, G.; Rinaldi, L.; Maurelli, M.P. Occurrence of Babesia Species and Co-Infection with Hepatozoon canis in Symptomatic Dogs and in Their Ticks in Eastern Romania. Pathogens 2021, 10, 1339. https://doi.org/10.3390/ pathogens10101339

Academic Editors: Donato Traversa, Angela Di Cesare and Simone Morelli

Received: 23 August 2021

Accepted: 11 October 2021

Published: 17 October 202

Publisher's Note: MDPI stays neutral with regard to jurisdictional claims in published maps and institutional affiliations.

Copyright: (c) 2021 by the authors. Licensee MDPI, Basel, Switzerland. This article is an open access article distributed under the terms and conditions of the Creative Commons Attribution (CC BY) license (https:/ / creativecommons.org/licenses/by/ $4.0 /)$.
Abstract: Although the distribution of Babesia spp. and Hepatozoon canis is well known in Romania, there is still a marked lack of information in many places of the country. This study aimed to investigate the occurrence of these haemoparasites in symptomatic dogs and in their ticks in Iasi, eastern Romania. Ninety owned dogs were subjected to clinical examination at the Faculty of Veterinary Medicine of Iasi and all detectable ticks ( 58 ticks from 15 dogs) were collected. Additionally, 124 ticks collected from the coat of other dogs (no. =23) were included. Three Babesia species were found in dogs: Babesia canis (94.4\%), Babesia vogeli (3.3\%), and Babesia rossi $(2.2 \%)$. All the dogs resulted negative for $H$. canis. The ticks were identified as follows: Ixodes ricinus (64\%), Dermacentor reticulatus (33\%), and Rhipicephalus sanguineus group (3\%). B. canis (Minimum Infection Rate; MIR $=81 \%)$, B. vogeli $(\mathrm{MIR}=3 \%)$, and Babesia microti-like piroplasm $(\mathrm{MIR}=1 \%)$ were found in ticks. Moreover, 15 ticks were positive for $H$. canis, 6 were co-infected with B. canis, and 1 with B. microti-like piroplasm. This is the first molecular identification of B. rossi in two symptomatic dogs from Romania, although further studies are needed to investigate the vector competence of other ticks from Europe.

Keywords: Babesia species; B. rossi; dogs; ticks; Romania

\section{Introduction}

In the last years, tick-borne pathogens (TBP) increased their prevalence and distribution, due to climate change, globalization, population movements, and growth, thus representing a serious problem for animals and humans [1-3]. Intracellular apicomplexan haemoparasites such as Babesia spp. and Hepatozoon canis are of particular concern to veterinarians because of the severe infections they cause in dogs and their wide geographic distribution [4-11]. Canine babesiosis, caused by different Babesia species, is transmitted by the bite of ixodid ticks, such as Dermacentor reticulatus (Babesia canis), Rhipicephalus sanguineus (Babesia vogeli), Haemaphysalis leachi and Haemaphysalis elliptica (Babesia rossi), Haemaphysalis longicornis, Haemaphysalis bispinosa and R. sanguineus (Babesia gibsoni), and involves erythrocytes [12-15]. Instead, H. canis is transmitted by ingestion of infected $R$. sanguineus group ticks and infects leukocytes [16,17]. The sexual reproduction for both Babesia spp. and H. canis occurs in the ticks, while asexual reproduction takes place in the vertebrae of intermediate hosts $[2,18]$.

Clinical babesiosis are usually associated with anaemia and haemolysis, fever, and lethargy, and may progress to multi-organ failure with a risk of mortality $[9,19,20]$. The broad spectrum of clinical signs depends on the different degrees of virulence of the Babesia 
species, but also on several factors related to hosts including age, splenectomy, immune competence, and concomitant infections or diseases [21-24]. In addition, the severity of illness has been associated with high parasitaemia in $B$. rossi infections $[25,26]$. Other species, i.e., B. vogeli can cause a subclinical to moderate clinical disease with possibly severe haemolytic anaemia in young dogs [22]. Moreover, a new piroplasmid species, Babesia negevi n. sp., has been recently described in a dog with a fatal disease [27]. However, little is known regarding the correlation between the disease severity and parasite density in other Babesia species.

The infection caused by H. canis is usually asymptomatic in dogs and is associated with low parasitaemia and mild disease, but severe disease with fever, lethargy, cachexia, and anaemia can be associated with high level of parasitaemia [28-30].

In Romania, several studies provided data on the identification of B. canis, B. vogeli, and B. gibsoni in dogs by means of molecular and serological analyses $[5,9,10,31,32]$. Moreover, H. canis infection has been identified in dogs, foxes, and jackals in Romania $[10,18,33,34]$. Although the distribution of Babesia spp. and H. canis is well known in several parts of Romania, there is still a lack of information in many places of the country. Therefore, the aim of this study was to investigate the occurrence of Babesia species and the co-infection with H. canis in dogs suspected of babesiosis and in their ticks in Iasi, eastern Romania.

\section{Results}

\subsection{Dogs}

Thirty-five dogs (38.9\%; 95\% CI = 29.0-49.8) showed mild clinical signs and 55 (61.1\%; $95 \% \mathrm{CI}=50.2-71.0$ ) expressed the acute form, attributable to babesiosis. All 90 of the sampled dogs that tested positive for the babesial parasites using a stained thin blood smear were positive for the general piroplasmid PCR. Three Babesia species were found in dogs: B. canis $(85 / 90=94.4 \% ; 95 \% \mathrm{CI}=86.9-97.9)(99.1-100 \%$ identity with GenBank Accession numbers: MK571831), B. vogeli ( $3 / 90=3.3 \% ; 95 \%$ CI $=0.9-10.1)(100 \%$ identity with GenBank Accession number: KY290979), and B. rossi $(2 / 90=2.2 \%$; $95 \% \mathrm{CI}=0.4-8.6)$ (100\% identity with GenBank Accession Number: MT740273). All the dogs resulted negative for $H$. canis.

Additionally, the dogs that expressed acute clinical signs were positive for B. canis with the prevalence of $58.9 \%(95 \% \mathrm{CI}=48.0-69.0)$ and B. rossi with the prevalence of $2.2 \%$ (95\% CI $=0.4-8.6)$. The dogs that showed mild clinical signs were positive for B. canis with the prevalence of $35.6 \%(95 \% \mathrm{CI}=25.9-46.4)$ and $B$. vogeli with the prevalence of $3.3 \%$ $(95 \%$ CI $=0.9-10.1)$.

Prevalence values were higher in dogs between 1 and 3 years $(58.9 \%$; $95 \% \mathrm{CI}=$ $48.0-69.0)$ and in males $(52.2 \% ; 95 \% \mathrm{CI}=41.5-62.7)$. The most frequently affected breeds were crossbreeds $(52.2 \%$; $95 \% \mathrm{CI}=41.5-62.8)$, followed by Peking dogs $(14.4 \%$; $95 \% \mathrm{CI}$ $=8.2-23.8)$ and German Shepherds $(10 \% ; 95 \% \mathrm{CI}=4.9-18.6)$. All the dogs presented tick infestation histories and $74.4 \%(67 / 90 ; 95 \% \mathrm{CI}=63.9-82.8)$ had access to the outdoors. All the dogs received one or two doses of imidocarb-dipropionate $(6.6 \mathrm{mg} / \mathrm{kg}$, at two weeks apart; Imizol; Intervet) and additional supportive therapy, depending on the clinical disorders expressed. Moreover, five dogs have died (5.6\%, four infected with B. canis and one with B. rossi) and for three of them the follow-up remains unknown. Overall, $91.1 \%$ of the dogs have recovered. The percentage of $B$. canis-infected dogs with access to the outdoors was significantly higher $(p<0.001)$ compared to dogs with an indoor lifestyle. Moreover, a statistically significant association was found between young dogs (1-3 years) and positivity for B. canis $(p<0.005)$. No statistically significant association was found between breed or gender and the positivity of Babesia species (Table 1). 
Table 1. Gender, age categories, breed, lifestyle, clinical form of babesiosis, tick infestation history, exposure of ticks during the routine visit and prevalence of Babesia spp. for 90 dogs included in the study.

\begin{tabular}{cc}
\hline Variable & Babesial Prevalence (95\% CI) \\
\hline Gender & \\
Males & $52.2 \%(41.5-62.7)$ \\
Females & $47.8 \%(37.2-58.5)$ \\
Age categories (years) & \\
Puppies (>1) & $5.6 \%(2.1-13.1)$ \\
$1-3$ & $58.9 \%(48.0-69.0)$ \\
$4-6$ & $13.3 \%(7.4-22.5)$ \\
$7-10$ & $10 \%(4.9-18.6)$ \\
$>10$ & $12.2 \%(6.6-21.2)$ \\
Dog breeds & \\
Cross-breed & $52.2 \%(41.5-62.8)$ \\
Peking & $14.4 \%(8.2-23.8)$ \\
German Sheperd & $10 \%(4.9-18.6)$ \\
Akita & $2.2 \%(0.4-8.6)$ \\
Beagle & $5.6 \%(2.1-13.1)$ \\
Caucasian Sheperd & $4.4 \%(1.4-11.6)$ \\
Bullmastiff & $1.1 \%(0.1-6.9)$ \\
Bull terrier & $3.3 \%(0.9-10.1)$ \\
Boxer & $6.7 \%(2.7-14.5)$ \\
Lifestyle & \\
Outdoors & $74.4 \%(63.9-82.8)$ \\
Indoors & $25.6 \%(17.2-36.0)$ \\
Total dogs analysed (90) & $100 \%(94.9-99.9)$ \\
Tick infestation history & \\
Dogs & $16.7 \%(9.9-26.3)$ \\
With ticks & $83.3 \%(73.7-90.0)$ \\
Without ticks & \\
Babesiosis & $61.1 \%(50.2-71.0)$ \\
Mild & $38.9 \%(28.9-49.8)$ \\
\hline & $100 \%(94.9-99.9)$ \\
\hline
\end{tabular}

\subsection{Ticks}

Dogs that presented with ticks during the routine visit were $33.6 \%$ of the total $(38 / 113$; $95 \% \mathrm{CI}=25.1-43.2)$. Briefly, $71.1 \%(27 / 38 ; 95 \% \mathrm{CI}=53.9-84.0)$ of dogs showed low infestation, $21.1 \%(8 / 38 ; 95 \% \mathrm{CI}=10.1-37.8)$ showed moderate infestation and $7.9 \%(3 / 38$; $95 \% \mathrm{CI}=2.1-22.5)$ showed high infestation. A total of 182 ticks were collected from dogs; of these, 58 ticks were found on $15 / 90(16.7 \%$; $95 \%$ CI $=9.9-26.3)$ symptomatic dogs and 124 ticks on another 23 dogs previously analysed for piroplasmosis (as above described). Specifically, 179 adults (113 engorged females and 66 males), 2 nymphs, and 1 larva were found (Table 2). One hundred tick sub-samples were prepared and identified as follows: Ixodes ricinus (64\%; 95\% CI $=53.7-73.2)$, Dermacentor reticulatus $(33 \%$; $95 \% \mathrm{CI}=24.1-43.2)$, and the Rhipicephalus sanguineus group (3\%; $95 \% \mathrm{CI}=0.8-9.1$ ). Babesia canis (MIR $=81 \%$; 95\% CI $=71.7-87.9)(99.8-100 \%$ identity with GenBank Accession numbers: MK571831, accessed on 1 March 2021), B. vogeli (MIR $=3 \%$; $95 \%$ CI $=0.78-9.6)(100 \%$ identity with GenBank Accession number: KY290979, accessed on 1 March 2021) and B. microti-like piroplasm (MIR $=1 \% ; 95 \% \mathrm{CI}=0.1-6.2)(100 \%$ identity with GenBank Accession number: MN355504,) was found in ticks. In addition, 15 ticks were positive for $H$. canis (MIR $=15 \%$; $95 \% \mathrm{CI}=8.9-23.9)$, six were co-infected with B. canis, and one with B. microti-like piroplasm (Table 2). 
Table 2. Results of species and life-stages of ticks (total number collected and total pools) and pathogen species identified.

\begin{tabular}{|c|c|c|c|}
\hline Species & $\begin{array}{c}\text { No. of Ticks } \\
\text { (Females/Males/Nymphs/Larvae) }\end{array}$ & $\begin{array}{c}\text { No. Pools } \\
\text { (Females/Males/Nymphs/Larvae) }\end{array}$ & $\begin{array}{l}\text { Pathogen } \\
\text { Species }\end{array}$ \\
\hline Ixodes ricinus & $112(73 / 38 / 1 / 0)$ & $64(45 / 19 / 1 / 0)$ & $\begin{array}{c}* \text { B. canis }(n=55) \\
* H \text {. canis }(n=15) \\
* \text { B. microti-like } \\
\text { piroplasm }(n=1)\end{array}$ \\
\hline Dermacentor reticulatus & $67(39 / 28 / 0 / 0)$ & $33(20 / 13 / 0 / 0)$ & B. canis $(n=33)$ \\
\hline Rhipicephalus sanguineus group & $3(1 / 0 / 1 / 1)$ & $3(1 / 0 / 1 / 1)$ & B. vogeli $(n=3)$ \\
\hline
\end{tabular}

* Co-infections: B. canis + H. canis (no. $=6$ ); H. canis + B. microti-like piroplasm $(n=1)$.

\section{Discussion}

We herein report the first comprehensive molecular survey of Babesia spp. and H. canis in owned dogs and in their ticks from the eastern part of Romania. More than $90 \%$ of the dogs and over $80 \%$ of the ticks collected from symptomatic dogs were positive for B. canis. Indeed, B. canis is a major cause of babesiosis in dogs from Romania, based on serological and molecular studies previously conducted in the southern and western parts of the country $[5,6,8,35,36]$. However, based on the findings reported by Andersson et al. [18], there might be a great variety of genotypes of this parasite in Romania [18]. Moreover, a high percentage of $B$. canis infected dogs with acute signs of clinical disease in Romania were imported from Hungary [5], thus highlighting that imported dogs with B. canis may play a critical role as reservoir hosts when introduced in areas free of this pathogen but with the presence of the vector tick.

More than $60 \%$ of the B. canis-infected dogs from the present study expressed acute clinical signs, which agrees with other studies conducted in Romania, Italy, and Hungary $[5,9,37,38]$. There are many reports attesting that the presence of Babesia species is highly associated with the geographical distribution of their vectors $[5,39,40]$. Several cases of canine babesiosis were reported from new areas of Germany, Hungary, Switzerland, and the Netherlands, due to the fact that $D$. reticulatus ticks were introduced in those areas [41-45]. However, B. canis has been found in areas where the presence of D. reticulatus is rare (e.g., the insular regions of Greece) [46]. The presence of B. canis and B. vogeli in dogs from the present study is also supported by the tick species that were found (I. ricinus = $64 \%$, D. reticulatus $=33 \%$ and $R$. sanguineus group $=3 \%$ ). In Romania, D. reticulatus was reported as the most common tick (67.2\%) infecting dogs in the south, west, north, and central areas, followed by the $R$. sanguineus group $(32.8 \%)[8,36,47,48]$. The Rhipicephalus sanguineus group was also reported with an increased prevalence in the urban areas of Romania, including the southern area of Bucharest [49,50]. Only one study [51] has recently reported the presence of D. reticulatus in Iasi County, the same area from the present study, but the authors did not identify I. ricinus ticks as we reported herein. Moreover, almost half of all I. ricinus ticks removed from dogs were Babesia-positive, and the total prevalence of B. canis in I. ricinus ticks was higher than in D. reticulatus ticks (55\% vs. 33\%). However, additional studies are warranted to obtain further information of the actual spread of the tick species and their transmitted pathogens to dogs in the eastern part of Romania. We found no cases of $H$. canis infection in dogs, but 15 I. ricinus ticks were positive for $H$. canis, 6 were co-infected with $B$. canis, and 1 with B. microti-like piroplasm. The results are not in agreement with several studies from southern, western, central, and northern Romania, where we found an important prevalence of $H$. canis in both dogs and ticks, ranging from $15 \%$ to $48 \%[10,18,34]$. However, our results showed that $H$. canis DNA was detected in I. ricinus ticks, similarly to the study by Andersson et al. [8]. Hepatozoon canis had been identified in I. ricinus ticks [52-54] collected from foxes and dogs, but this tick species is not acknowledged as a competent vector for $H$. canis [55]. Instead, there are other studies $[18,56,57]$ which show that $H$. canis DNA was not detected in $R$. sanguineus south-eastern lineage ticks, or that report $H$. canis infections in areas where $R$. sanguineus ticks are not present [58], although this tick species is considered to be the main vector for 
$H$. canis $[59,60]$. On the other side, there are several studies that revealed the presence of co-infections with multiple tick-borne pathogens (TBP) in dogs, such as: H. canis, Babesia spp, Ehrlichia canis, and Anaplasma platys [61,62], as well as ticks that harbour the DNA of some pathogens which were not detected in their host blood samples [63]. Additionally, our study found H. canis DNA in ticks (I. ricinus), but not in the blood of the dogs, demonstrating that this pathogen circulates in Iasi, in the north-eastern part of Romania. The presence of co-infections with two or more TBPs, i.e., Babesia and Hepatozoon, may result in greater pathogenicity and more complications for the infected dogs. Despite of the availability of the ectoparasiticides and anti-feeding products, dogs are highly exposed to vector-borne diseases (VBD). There are many studies attesting that the majority of the dogs, not only the stray or kennelled dogs but owned dogs too, did not receive adequate preventative treatments in order to protect the animals from ticks, fleas, and sandfly or mosquito infestations [64-66]. Moreover, feline hepatozoonosis is an emerging VBD, and cats can be infected with Hepatozoon felis but also with $H$. canis. Thus, the protection of dogs could limit the circulation of pathogens (including H. canis) that could threaten the health of other animals [67].

In Romania, several studies reported different ranges of prevalence of B. gibsoni in symptomatic dogs from western and north-western Romania [31]. The lack of B. gibsoni infections in our study might be explained by a low number of cases of this infection in eastern Romania. Similar results were recently obtained in the southern part of Romania [10]. An unexpected outcome from the present study was the molecular identification of $B$. rossi in two symptomatic dogs. Indeed, one dog died and the other one was successfully treated. The main clinical signs displayed by the infected dogs were anorexia, fever, haemoglobinuria, anaemia, constipation alternating with diarrhoea, and splenomegaly. Actually, we cannot fully explain these results. However, the black-backed jackal (Canis mesomelas) is considered the natural reservoir host of $B$. rossi and $H$. elliptica, the most prevalent tick in jackal populations in the eastern and north-eastern parts of South Africa, and has the capacity of transmitting $B$. rossi [11]. A recent study revealed an unexpected outcome, showing no positivity of B. rossi in the black-backed jackal populations from South Africa [68]. To the authors' knowledge, neither the vector or the pathogen of B. rossi was detected in Romania. However, the golden jackal (Canis aureus) is present throughout the country [69,70] and has already been incriminated as a potential natural reservoir of Dirofilaria spp. [71]. Perhaps, we can extend the hypothesis of the role of golden jackal populations or other wild canids such as wolves (Canis lupus) and red foxes (Vulpes vulpes) in maintaining the life cycle of $B$. rossi in Romania. In addition, the golden jackal is widespread in Europe, and an ongoing expansion of these wild canids has been reported in the Balkan Peninsula [72-74]. However, there are only three cases reported with B. rossi in Western Europe (France, Germany, and Switzerland) in a study that aimed to report the occurrence of Babesia spp. DNA in over 100,000 samples from America, Europe, Asia, and Oceania [75]. Further studies are needed to identify the tick species and their vector competence for canine babesiosis caused by $B$. rossi in Romania. The limitations of this study were as follows: (i) we collected mostly adult ticks from dogs, because this life-stage is easier to detect during the clinical examination. Molecular studies on larvae and nymphs could be useful to evaluate any differences in transmission of pathogens with adults; (ii) the small size of the blood samples collected from the symptomatic dogs and their ticks was not enough to identify the real picture of $H$. canis in the eastern part of Romania, knowing that there is high prevalence of $H$. canis infection in south, west, and central areas of Romania [8,10,18]; (iii) we identified only three $R$. sanguineus group ticks collected from dogs, which was an irrelevant number, in order to provide a conclusive screening on the actual spread of this tick in the studied area; (iv) we have not performed a follow-up of the two cases infected with $B$. rossi because one dog died and the owner did not approve the necropsy. The owner of the other dog that is still alive did not collaborate with us for further analyses; and (v) finally, we have not performed phylogenetic analyses. 


\section{Materials and Methods}

\subsection{Study Design and Samples Collection}

The study was carried out in 2019 at the Clinics of the Faculty of Veterinary Medicine of Iasi, in the eastern part of Romania, on 90 owned dogs that showed clinical signs compatible with babesiosis (hyperthermia, haemolytic anaemia, thrombocytopenia, icterus, and haemoglobinuria) [21]. General information on the dogs' age, breed, gender, tick infestation history, and outdoor access was provided by the owners. The ages of the dogs were grouped into five categories as follows: puppies (less than 1 year of age); young (1-3 years); adult (4-6 years); old (7-10 years); and very old ( $>10$ years). All the dogs came from both urban and suburban areas of Iasi County and had no recorded history of travelling outside Romania.

EDTA-anticoagulated whole blood samples were collected from dogs that were enrolled and analysed for babesial parasites using quick Romanowsky stained thin blood smears. Briefly, thin air-dried blood smears were stained using a Diff Stain Quick kit (Pro-Eko S.r.l, Molise, Italy) and examined by an optical microscope at 1000X for detection of intra-erythrocytic piroplasms [23]. An aliquot of all the blood samples were stored at $-20^{\circ} \mathrm{C}$ until DNA was extracted for Babesia spp. and H. canis molecular detection.

Each dog was submitted to a clinical examination, and all detectable ticks were collected for species identification by standard taxonomic keys [76,77]. Moreover, life-stage, sex, and engorgement status of all the ticks collected from the coat of the dogs (No. $=15$ ) were determined under a stereomicroscope. Additionally, 124 ticks collected from the coats of the other 23 dogs previously diagnosed with babesiosis by stained blood smears were included in the study. No information regarding the signalment data or clinical findings was provided for the dogs mentioned above. Moreover, the screening for Babesia species and H. canis in their blood was not performed. A scoring system has been used to express intensity of ticks per infested host, according to the World Association for the Advancement of Veterinary Parasitology (WAAVP) guidelines as follows (score-number of ticks/per animal) (None: 0; Low: 1-3; Moderate: 4-10; High: > 10) [78].

Collected ticks were stored in $70 \%$ ethanol and separated by individual animal for morphological detection.

All identified ticks $($ No. $=182)$ were divided into No. $=100$ sub-samples (nine composed by pools of three ticks, 64 by pools of two ticks, and 27 sub-samples individually analysed) comprised of specimens collected from the same dog, and homogeneous species that were screened for Babesia species and H. canis using molecular analyses (Table 3).

Table 3. Study design.

\begin{tabular}{cc}
\hline Samples Collection & Laboratory Analyses \\
\hline $\begin{array}{c}\text { Blood samples from symptomatic dogs } \\
\text { (no. }=90) \text { and collection of ticks (no. }=58 \text { ticks } \\
\text { present on 15 dogs) }\end{array}$ & $\begin{array}{c}\text { Quick Romanowsky stained-thin blood } \\
\text { smear [23] for detection of intra-erythrocytic } \\
\text { piroplasms }\end{array}$ \\
$\begin{array}{c}\text { DNA extraction, PCR amplification and } \\
\text { sequencing [79,80] for Babesia spp. and H. canis } \\
\text { Morphological identification of the ticks [76,77] }\end{array}$ \\
\hline $\begin{array}{c}\text { 124 ticks collected from the coat of other } \\
\text { 23 dogs previously diagnosed with babesiosis } \\
\text { by stained blood smears }\end{array}$ & $\begin{array}{c}\text { Morphological identification of the ticks [76,77] } \\
\text { Total number of tick sub-samples (no. =100) }\end{array}$ \\
\hline
\end{tabular}

\subsection{DNA Extraction, PCR Amplification and Sequencing}

All the blood and tick samples were transferred to the University of Federico II, Department of Veterinary Medicine and Animal Production, in Naples, Italy, where DNA extractions and molecular screenings were performed. DNA was extracted from $200 \mu \mathrm{L}$ 
of blood in EDTA tubes (No. $=90$ blood samples) and from ticks (No. $=100$ pools) using the DNeasy Blood \& Tissue kit (Qiagen, Leipzig, Germany) according to the manufacturer's instructions. The ethyl alcohol was removed prior to DNA extraction. Quality and quantity of the extracted DNA were checked with a spectrophotometer (Multiskan GO, Thermo Fisher Scientific, MA, USA). The extracted DNA was stored at $-20^{\circ} \mathrm{C}$. Specific primers were used to amplify the 18S rRNA gene fragment of Babesia/Theileria (559 bp): BabGF:5'-GYYTTGTAATTGGAATGATGG-3'; BabGR: 5' - CCAAAGACTTTGATTTCTCTC$3^{\prime}$ [79]; and H. canis (666bp): HepF:5' ATACATGAGCAAAATCTCAAC -3'; Hep R: 5'CTTATTATTCCATGCTGCAG - $3^{\prime}$ [80].

Reactions were performed using the PCR protocol described by Bajer et al. [79] with some modifications for Babesia spp. Detection: a single end-point PCR was performed preparing a total $25 \mu \mathrm{L}$ PCR volume $(22 \mu \mathrm{L}$ of PCR mix $+3 \mu \mathrm{L}$ of the extracted DNA sample) for each sample with $1 \mathrm{x}$ buffer (EcoTaq PLUS, Lucigen, WI, USA) and $0.5 \mu \mathrm{M}$ of each primer [79]. For H. canis, PCR was performed according to Inokuma et al. [80]. The PCR products were detected on a $1.5 \%$ ethidium bromide-stained low melting agarose gel (BIO-RAD, Spain). Babesia canis and H. canis DNA samples were used as positive controls, while PCR water was used as a negative control.

Since the tick sub-samples were composed of one-three ticks, the PCR results were expressed as a minimum infection rate (MIR), meaning the minimum percentage of ticks in a pool with detectable DNA for each specific pathogen. It was assumed that a PCRpositive sub-sample contains only one positive tick (also for sub-samples with two-three ticks) $[81,82]$.

The amplified target DNAs for Babesia spp. and H. canis were purified with QIAquick PCR Purification Kit according to the manufacturer's instruction (Qiagen, Hilden, Germany) and sequenced with forward and reverse primers (Eurofins, Martinsried, Germany). Sequencing results were analysed with the Chromas version 2.6.6 software (www.technelysium.com.au, accessed on 20 February 2019). DNA sequence comparisons were achieved by BLAST (www.ncbi.nlm.nih.gov, last accessed on 1 March 2021).

\subsection{Statistical Analysis}

Chi-square tests and confidence intervals at 95\% (95\% CI) were calculated using SPSS Statistics v.23 (IBM, Armonk, NY, USA) to verify the possible associations between dogs' data (breed, age, gender, and access to outdoors) and the prevalence of the Babesia species. Differences were considered significant at $p<0.05$.

\section{Conclusions}

The study revealed the first identification of $B$. rossi in two symptomatic dogs from Romania, although further studies are needed to confirm the presence of this pathogen and its vector in Europe and Romania and to investigate the vector competence of tick species that might be acting as vectors for this pathogen. Our study also demonstrated a high prevalence of $B$. canis and a low prevalence of B. vogeli in dogs and in their ticks in the eastern part of Romania; therefore, the genetic characterization of Babesia species could help practitioners select the appropriate testing and treatments, and for understanding the risks of infection, knowing that $B$. canis is considered more pathogenic than $B$. vogeli. Moreover, we can underline once more the importance of the molecular characterization of Babesia species and related pathogenicity in dogs, sustained as well by data that reveals the first description of a new piroplasmid species, Babesia negevi n. sp., in a dog with a fatal disease in southern Israel [27] and, recently, in Jordan too [83].

Author Contributions: Conceptualization, L.C. and G.M.; Methodology, L.C. and G.M; Validation, M.P.M., L.R. and L.D.M.; Formal Analysis, L.C., D.A., G.M. and C.R.; Investigation, L.C. and G.M.; Data Curation, L.C., D.A., G.M. and C.R.; Writing-Original Draft Preparation, L.C., G.M. and M.P.M.; Writing-Review and Editing, M.P.M., L.R., L.D.M. and G.C.; Supervision, L.R and G.C; Project Administration, L.C. and M.P.M. All authors have read and agreed to the published version of the manuscript. 
Funding: This research received no external funding.

Institutional Review Board Statement: The study was conducted according to the guidelines of the Declaration of Helsinki, and approved by the Ethics Committee of Faculty of Veterinary Medicine (protocol code 1551/6 February 2019).

Acknowledgments: The authors would like to thank to Anna Bajer, Ewa Julia Mierzejewska, and their team from the University of Warsaw for providing us with the positive controls of Hepatozoon spp. for the molecular analysis.

Conflicts of Interest: The authors declare no conflict of interest.

\section{References}

1. Dantas-Torres, F.; Chomel, B.B.; Otranto, D. Ticks and tick-borne diseases: A one health perspective. Trends Parasitol. 2012, 28, 437-446. [CrossRef]

2. Baneth, G.; Bourdeau, P.; Bourdoiseau, G.; Bowman, D.; Breitschwerdt, E.; Capelli, G.; Cardoso, L.; Dantas-Torres, F.; Day, M.; Dedet, J.-P.; et al. Vector-Borne Diseases—constant challenge for practicing veterinarians: Recommendations from the CVBD World Forum. Parasites Vectors 2012, 5, 55. [CrossRef]

3. Banović, P.; Díaz-Sánchez, A.A.; Galon, C.; Foucault-Simonin, A.; Simin, V.; Mijatović, D.; Papić, L.; Wu-Chuang, A.; Obregón, D.; Moutailler, S.; et al. A one health approach to study the circulation of tick-borne pathogens: A preliminary study. One Health 2021, 13, 100270. [CrossRef] [PubMed]

4. Otranto, D.; Dantas-Torres, F.; Weigl, S.; Latrofa, M.S.; Stanneck, D.; Decaprariis, D.; Capelli, G.; Baneth, G. Diagnosis of Hepatozoon canis in young dogs by cytology and PCR. Parasites Vectors 2011, 4, 55. [CrossRef]

5. Hamel, D.; Silaghi, C.; Lescai, D.; Pfister, K. Epidemiological aspects on vector-borne infections in stray and pet dogs from Romania and Hungary with focus on Babesia spp. Parasitol. Res. 2011, 110, 1537-1545. [CrossRef] [PubMed]

6. Imre, M.; Farkas, R.; Ilie, M.; Imre, K.; Hotea, I.; Morariu, S.; Morar, D.; Dărăbuş, G. Seroprevalence of Babesia canis infection in clinically healthy dogs from Western Romania. J. Parasitol. 2013, 99, 161-163. [CrossRef]

7. Solano-Gallego, L.; Sainz, Á.; Roura, X.; Peña, A.E.; Miró, G. A review of canine babesiosis: The European perspective. Parasites Vectors 2016, 9, 1-18. [CrossRef]

8. Andersson, M.O.; Tolf, C.; Tamba, P.; Stefanache, M.; Waldenström, J.; Dobler, G.; Chitimia-Dobler, L. Canine tick-borne diseases in pet dogs from Romania. Parasites Vectors 2017, 10, 155. [CrossRef]

9. Leica, L.; Mitrea, I.L.; Ionita, M. Clinical occurrence of canine babesiosis in the coastal area of the Black Sea (Dobrogea) in southeastern Romania and associated epidemiological implications. J. Parasitol. 2019, 105, 491-496. [CrossRef] [PubMed]

10. Cimpan, A.A.; Nachum-Biala, Y.; Ben-Shitrit, B.; Miron, L.; Baneth, G. Epidemiological study of canine babesiosis and hepatozoonosis in the South of Romania. Acta Parasitol. 2020, 65, 669-678. [CrossRef] [PubMed]

11. Penzhorn, B.L. Don't let sleeping dogs lie: Unravelling the identity and taxonomy of babesia canis, babesia rossi and babesia vogeli. Parasites Vectors 2020, 13, 1-9. [CrossRef] [PubMed]

12. Dantas-Torres, F. The brown dog tick, Rhipicephalus sanguineus (Latreille, 1806) (Acari: Ixodidae): From taxonomy to control. Vet. Parasitol. 2008, 152, 173-185. [CrossRef] [PubMed]

13. Foldvari, G.; Široký, P.; Szekeres, S.; Majoros, G.; Sprong, H. Dermacentor reticulatus: A vector on the rise. Parasites Vectors 2016, 9, 1-29. [CrossRef] [PubMed]

14. Rizzoli, A.; Silaghi, C.; Obiegala, A.; Rudolf, I.; Hubálek, Z.; Földvári, G.; Plantard, O.; Vayssier-Taussat, M.; Bonnet, S.; Spitalská, E.; et al. Ixodes ricinus and its transmitted pathogens in urban and peri-urban areas in Europe: New hazards and relevance for public health. Front. Public Health 2014, 1, 251. [CrossRef]

15. Gray, J.S.; Estrada-Peña, A.; Zintl, A. Vectors of Babesiosis. Annu. Rev. Èntomol. 2019, 64, 149-165. [CrossRef] [PubMed]

16. Greene, C.E. Feline enteric viral infections. In Infectious Diseases of the Dog and Cat, 4th ed.; Elsevier/Sounders: St. Lousis, MO, USA, 2012; pp. 771-784.

17. Levi, M.M.; Nachum-Biala, Y.; King, R.; Baneth, G. A survey of Babesia spp. and Hepatozoon spp. in wild canids in Israel. Parasites Vectors 2018, 11, 150. [CrossRef] [PubMed]

18. Andersson, M.O.; Tolf, C.; Tamba, P.; Stefanache, M.; Radbea, G.; Rubel, F.; Waldenström, J.; Dobler, G.; Chițimia-Dobler, L. Babesia, Theileria, and Hepatozoon species in ticks infesting animal hosts in Romania. Parasitol. Res. 2017, 116, $2291-2297$. [CrossRef] [PubMed]

19. Kraje, A.C. Canine haemobartonellosis and babesiosis. Compend. Contin. Educ. Pract. Vet. 2001, 23, 310-318.

20. Ullal, T.; Birkenheuer, A.; Vaden, S. Azotemia and proteinuria in dogs infected with Babesia gibsoni. J. Am. Anim. Hosp. Assoc. 2018, 54, 156-160. [CrossRef] [PubMed]

21. Irwin, P.J. Canine babesiosis: From molecular taxonomy to control. Parasites Vectors 2009, 2, 1-9. [CrossRef]

22. Solano-Gallego, L.; Baneth, G. Babesiosis in dogs and cats-Expanding parasitological and clinical spectra. Veter. Parasitol. 2011, 181, 48-60. [CrossRef]

23. Lempereur, L.; Beck, R.; Fonseca, I.; Marques, C.; Duarte, A.; Santos, M.; Zúquete, S.; Gomes, J.; Walder, G.; Domingos, A.; et al. Guidelines for the detection of Babesia and Theileria Parasites. Vector Borne Zoonotic Dis. 2017, 17, 51-65. [CrossRef] [PubMed] 
24. Galán, A.; Mayer, I.; Rafaj, R.B.; Bendelja, K.; Sušić, V.; Cerón, J.J.; Mrljak, V. MCP-1, KC-like and IL-8 as critical mediators of pathogenesis caused by Babesia canis. PLoS ONE 2018, 13, e0190474. [CrossRef] [PubMed]

25. Böhm, M.; Leisewitz, A.L.; Thompson, P.N.; Schoeman, J.P. Capillary and venous Babesia canis rossi parasitaemias and their association with outcome of infection and circulatory compromise. Veter. Parasitol. 2006, 141, 18-29. [CrossRef] [PubMed]

26. Leisewitz, A.; Goddard, A.; De Gier, J.; Van Engelshoven, J.; Clift, S.; Thompson, P.; Schoeman, J.P. Disease severity and blood cytokine concentrations in dogs with natural Babesia rossi infection. Parasite Immunol. 2019, 41, e12630. [CrossRef]

27. Baneth, G.; Nachum-Biala, Y.; Birkenheuer, A.J.; Schreeg, M.E.; Prince, H.; Florin-Christensen, M.; Schnittger, L.; Aroch, I. A new piroplasmid species infecting dogs: Morphological and molecular characterization and pathogeny of Babesia negevi n. sp. Parasites Vectors 2020, 13, 1-13. [CrossRef]

28. Little, S.E.; Allen, K.E.; Johnson, E.M.; Panciera, R.J.; Reichard, M.V.; Ewing, S.A. New developments in canine hepatozoonosis in North America: A review. Parasites Vectors 2009, 2, 1-4. [CrossRef] [PubMed]

29. Roopali, B.; Mahadappa, P.; Satheesha, S.P.; Sandeep, H.; Kasaralikar, V.; Patil, N.A. Acute hepatozoonosis in dogs: A case report. J. Parasit. Dis. 2017, 41, 747-749. [CrossRef]

30. Baneth, G. Perspectives on canine and feline hepatozoonosis. Veter Parasitol. 2011, 181, 3-11. [CrossRef]

31. Imre, M.; Farkas, R.; Ilie, M.S.; Imre, K.; Dărăbuş, G. Survey of babesiosis in symptomatic dogs from Romania: Occurrence of Babesia gibsoni associated with breed. Ticks Tick-Borne Dis. 2013, 4, 500-502. [CrossRef]

32. Ionita, M.; Mitrea, I.L.; Pfister, K.; Hamel, D.; Buzatu, C.M.; Silaghi, C. Canine babesiosis in Romania due to Babesia canis and Babesia vogeli: A molecular approach. Parasitol. Res. 2011, 110, 1659-1664. [CrossRef] [PubMed]

33. Imre, M.; Dudu, A.; Ilie, M.S.; Morariu, S.; Imre, K.; Dărăbuş, G. Molecular Survey of Hepatozoon canis in Red Foxes (Vulpes vulpes) from Romania. J. Parasitol. 2015, 101, 490-491. [CrossRef]

34. Andersson, M.; Turcitu, M.A.; Stefanache, M.; Tamba, P.; Barbuceanu, F.; Chitimia, L. First evidence of Anaplasma platys and Hepatozoon canis co-infection in a dog from Romania-A case report. Ticks Tick Borne Dis. 2013, 4, 317-319. [CrossRef]

35. Ilie, M.S.; Darabus, G.; Imre, M.; Imre, K.; Hotea, I.; Sorescu, I. Survey of canine babesiosis in Banat area. Bull. UASVM Vet. Medicine. 2010, 67, 125-130.

36. Ionita, M.; Mitrea, I.L.; Pfister, K.; Hamel, D.; Silaghi, C. Molecular evidence for bacterial and protozoan pathogens in hard ticks from Romania. Veter. Parasitol. 2013, 196, 71-76. [CrossRef]

37. Solano-Gallego, L.; Trotta, M.; Carli, E.; Carcy, B.; Caldin, M.; Furlanello, T. Babesia canis canis and Babesia canis vogeli clinicopathological findings and DNA detection by means of PCR-RFLP in blood from Italian dogs suspected of tick-borne disease. Veter. Parasitol. 2008, 157, 211-221. [CrossRef]

38. Máthé, A.; Dobos-Kovács, M.; Voros, K. Histological and ultrastructural studies of renal lesions in Babesia canis infected dogs treated with imidocarb. Acta Veter. Hung. 2007, 55, 511-523. [CrossRef]

39. Guo, H.; Sevinc, F.; Ceylan, O.; Sevinc, M.; Ince, E.; Gao, Y.; Moumouni, P.F.A.; Liu, M.; Efstratiou, A.; Wang, G.; et al. A PCR survey of vector-borne pathogens in different dog populations from Turkey. Acta Parasitol. 2017, 62, 533-540. [CrossRef] [PubMed]

40. Gabrielli, S.; Otašević, S.; Ignjatović, A.; Savic, S.; Fraulo, M.; Arsić-Arsenijević, V.; Momčilović, S.; Cancrini, G. Canine Babesioses in Noninvestigated Areas of Serbia. Vector-Borne Zoonotic Dis. 2015, 15, 535-538. [CrossRef]

41. Barutzki, D.; Reule, M.; Scheunemann, R.; Heile, C.; Schein, E. Die Babesiose des Hundes. Dtsch. Tierärzteblatt $2007,3,284-293$.

42. Nijhof, A.M.; Bodaan, C.; Postigo, M.; Nieuwenhuijs, H.; Opsteegh, M.; Franssen, L.; Jebbink, F.; Jongejan, F. Ticks and Associated Pathogens Collected from Domestic Animals in the Netherlands. Vector Borne Zoonotic Dis. 2007, 7, 585-596. [CrossRef]

43. Sréter, T.; Széll, Z.; Varga, I. Spatial distribution of Dermacentor reticulatus and Ixodes ricinus in Hungary: Evidence for change? Veter. Parasitol. 2005, 128, 347-351. [CrossRef]

44. Heile, C.; Heydorn, A.O.; Schein, E. Dermacentor reticulatus (Fabricius, 1794)—Verbreitung, Biologie und Vektor von Babesia canis in Deutschland. Berl. Münch. Tierärztl. Wochenschr. 2006, 119, 330-334.

45. Hamel, D.; Röhrig, E.; Pfister, K. Canine vector-borne disease in travelled dogs in Germany-A retrospective evaluation of laboratory data from the years 2004-2008. Veter. Parasitol. 2011, 181, 31-36. [CrossRef] [PubMed]

46. Diakou, A.; Di Cesare, A.; Morelli, S.; Colombo, M.; Halos, L.; Simonato, G.; Tamvakis, A.; Beugnet, F.; Paoletti, B.; Traversa, D. Endoparasites and vector-borne pathogens in dogs from Greek islands: Pathogen distribution and zoonotic implications. PLoS Negl. Trop. Dis. 2019, 13, e0007003. [CrossRef]

47. Mihalca, A.D.; Dumitrache, M.O.; Magdas, C.; Gherman, C.M.; Domsa, C.; Mircean, V.; Ghira, I.V.; Pocora, V.; Ionescu, D.T.; Baraba, S. Synopsis of the hard ticks (Acari: Ixodidae) of Romania with update on host associations and geographical distribution. Exp. Appl. Acarol. 2012, 58, 183-206. [CrossRef]

48. Tudor, P.; Braslasu, D.E.; Fernoaga, C. Study on natural infestation with hard ticks on dogs in Bucharest. Sci. Work. -Univ. Agron. Sci. Vet. Med. Buchar. Ser. C Vet. Med. 2010, 56, 172-179.

49. Ioniţă, M.; Mitrea, I.L. Observations on the life cycle of the brown dog tick (Rhipicephalus sanguineus Latreille 1806, Acari: Ix-odidae), in the Buchraest's environment conditions. Sci. Parasitol. 2003, 4, 167-171.

50. Ioniţă, M.; Mitrea, I.L.; Buzatu, M.C.; Dascalu, L. Seasonal dynamics of tick (Acari: Ixodidae) populations in different areas of Romania and the associated risks of tick-borne diseases. In Proceedings of the XIIth International Congress of Parasitology (ICOPA), Melbourne, Australia, 15-20 August 2010; p. 665. 
51. Bratuleanu, B.E.; Temmam, S.; Chrétien, D.; Regnault, B.; Pérot, P.; Bouchier, C.; Bigot, T.; Savuța, G.; Eloit, M. The virome of Rhipicephalus, Dermacentor and Haemaphysalis ticks from Eastern Romania includes novel viruses with potential relevance for public health. Transbound. Emerg. Dis. 2021, 1-17. [CrossRef]

52. Najm, N.-A.; Meyer-Kayser, E.; Hoffmann, L.; Pfister, K.; Silaghi, C. Hepatozoon canis in German red foxes (Vulpes vulpes) and their ticks: Molecular characterization and the phylogenetic relationship to other Hepatozoon spp. Parasitol. Res. 2014, 113, 2679-2685. [CrossRef] [PubMed]

53. Reye, A.L.; Hübschen, J.M.; Sausy, A.; Muller, C.P. Prevalence and Seasonality of Tick-Borne Pathogens in Questing Ixodes ricinus Ticks from Luxembourg. Appl. Environ. Microbiol. 2010, 76, 2923-2931. [CrossRef]

54. Namina, A.; Capligina, V.; Seleznova, M.; Krumins, R.; Aleinikova, D.; Kivrane, A.; Akopjana, S.; Lazovska, M.; Berzina, I.; Ranka, R. Tick-borne pathogens in ticks collected from dogs, Latvia, 2011-2016. BMC Veter. Res. 2019, 15, 1-10. [CrossRef]

55. Giannelli, A.; Ramos, R.A.N.; Dantas-Torres, F.; Mencke, N.; Baneth, G.; Otranto, D. Experimental evidence against transmission of Hepatozoon canis by Ixodes ricinus. Ticks Tick-Borne Dis. 2013, 4, 391-394. [CrossRef] [PubMed]

56. Potkonjak, A.; Gutiérrez, R.; Savic, S.; Vračar, V.; Nachum-Biala, Y.; Jurišić, A.; Kleinerman, G.; Rojas, A.; Petrović, A.; Baneth, G.; et al. Molecular detection of emerging tick-borne pathogens in Vojvodina, Serbia. Ticks Tick-Borne Dis. 2016, 7, 199-203. [CrossRef] [PubMed]

57. Chitimia-Dobler, L.; Langguth, J.; Pfeffer, M.; Kattner, S.; Küpper, T.; Friese, D.; Dobler, G.; Guglielmone, A.A. Genetic analysis of ticks parasites of dogs in Africa north of the Sahara based on mitochondrial DNA sequences. Vet. Parasitol. 2017, 239, 1-6. [CrossRef] [PubMed]

58. Miterpáková, M.; Komjáti-Nagyová, M.; Hurníková, Z.; Víchová, B. Retrospective molecular study on canine hepatozoonosis in Slovakia-Does really infection risk for dogs exist? Ticks Tick Borne Dis. 2017, 8, 567-573. [CrossRef] [PubMed]

59. Baneth, G.; Samish, M.; Shkap, V. Life cycle of Hepatozoon canis (Apicomplexa: Adeleorina: Hepatozoidae) in the tick Rhipicephalus sanguineus and domestic dog (Canis familiaris). J. Parasitol. 2007, 93, 283-299. [CrossRef]

60. Christophers, S.R. The sexual life cycle of Leucocytozoon canis in the tick. Sci. Mem. Off. Med. Sanit. Dep. Gov. India 1907, 28, $1-11$.

61. Galay, R.L.; Manalo, A.A.L.; Dolores, S.L.D.; Aguilarm, I.P.M.; Sandalo, K.A.C.; Cruz, K.B.; Divina, B.P.; Andoh, M.; Masatani, T.; Tanaka, T. Molecular detection of tick-borne pathogens in canine population and Rhipicephalus sanguineus (sensu lato) ticks from southern Metro Manila and Laguna, Philippines. Parasites Vectors 2018, 11, 643. [CrossRef]

62. Bouattour, A.; Chabchoub, A.; Hajjaji, I.; M'ghirbi, Y. Hepatozoon canis and Babesia vogeli infections of dogs in Tunisia. Vet. Parasitol. Reg. Stud. Rep. 2021, 23, 100512.

63. Juasook, A.; Siriporn, B.; Nopphakhun, N.; Phetpoang, P.; Khamyang, S. Molecular detection of tick-borne pathogens in infected dogs associated with Rhipicephalus sanguineus tick infestation in Thailand. Vet. World 2021, 14, 1631-1637. [CrossRef] [PubMed]

64. Baneth, G.; Thamsborg, S.M.; Otranto, D.; Guillo, J.; Blaga, R.; Deplazes, P.; Solano-Gallego, L. Major parasitic zoonoses associated with dogs and cats in Europe. J. Comp. Pathol. 2016, 155, 54-74. [CrossRef] [PubMed]

65. Otranto, D. Arthropod-borne pathogens of dogs and cats: From pathways and times of transmission to disease control. Vet. Parasitol. 2018, 15, 68-77. [CrossRef]

66. Colombo, M.; Morelli, S.; Simonato, G.; Di Cesare, A.; Veronesi, F.; Frangipane Di Regalbono, A.; Grassi, L.; Russi, I.; Tiscar, P.G.; Morganti, G.; et al. Exposure to major vector-borne diseases in dogs subjected to different preventative regimens in endemic areas of Italy. Pathogens 2021, 10, 507. [CrossRef]

67. Morelli, S.; Diakou, A.; Traversa, D.; Di Gennaro, E.; Simonato, G.; Colombo, M.; Dimzas, D.; Grillini, M.; Frangipane Di Regalbono, A.; Beugnet, F.; et al. First record of Hepatozoon spp. in domestic cats in Greece. Ticks Tick Borne Dis. 2021, $12,101580$. [CrossRef]

68. Viljoen, S.; O’Riain, M.J.; Penzhorn, B.L.; Drouilly, M.; Vorster, I.; Bishop, J.M. Black-backed jackals (Canis mesomelas) from semi-arid rangelands in South Africa harbour Hepatozoon canis and a Theileria species but apparently not Babesia rossi. Vet. Parasitol. Reg. Stud. Reports. 2021, 24, 100559. [PubMed]

69. Angelescu, A. The Golden Jackal: Origin, Morphoanatomy, Eco-Etholgy, Management; MMC: Bucharest, Romania, 2004.

70. Papp, C.R.; Banea, O.C.; Szekely-Sitea, A.I. Applied ecology and management aspects related to the golden jackal specific ecological system in Romania. Acta Musei Maramorosiensis 2014, 9, 275-292.

71. Ionică, A.M.; Matei, I.A.; D’Amico, G.; Daskalaki, A.A.; Juránková, J.; Ionescu, D.T.; Mihalca, A.D.; Modrý, D.; Gherman, C.M. Role of golden jackals (Canis aureus) as natural reservoirs of Dirofilaria spp. in Romania. Parasites Vectors 2016, 28, 240. [CrossRef] [PubMed]

72. Arnold, J.; Humer, A.; Heltai, M.; Murariu, D.; Spassov, N.; Hackländer, K. Current status and distribution of golden jackals (Canis aureus L., 1758) in Europe. Mammal. Rev. 2012, 42, 1-11. [CrossRef]

73. Trouwborst, A.; Krofel, M.; Linnell, J.D.C. Legal implications of range expansions in a terrestrial carnivore: The case of the golden jackal (Canis aureus) in Europe. Biodivers. Conserv. 2015, 24, 2593-2610. [CrossRef]

74. Vasiliu, G. Verzeichnis der Säugetiere Rumäniens (Enumera ia mamiferelor din România). Säugetierkd Mitt. München 1961, 9 , $56-68$.

75. Birkenheuer, A.J.; Buch, J.; Beall, M.J.; Braff, J.; Chandrashekar, R. Global distribution of canine Babesia species identified by a commercial diagnostic laboratory. Vet. Parasitol. Reg. Stud. Rep. 2020, 22, 100471. [CrossRef] 
76. Estrada-Pena, A.; Bouattour, A.; Camicas, J.L.; Walker, A.R. Ticks of Domestic Animals in the Mediterranean Region: A guide to The Identification of Species, 1st ed.; University of Zaragoza: Zaragoza, Spain, 2004.

77. Dantas-Torres, F.; Latrofa, M.S.; Annoscia, G.; Giannelli, A.; Parisi, A.; Otranto, D. Morphological and genetic diversity of Rhipicephalus sanguineus sensu lato from the New and Old Worlds. Parasites Vectors 2013, 6, 213. [CrossRef] [PubMed]

78. Marchiondo, A.A.; Holdsworth, P.A.; Green, P.; Blagburn, B.L.; Jacobs, D.E. World Association for the Advancement of Veterinary Parasitology (W.A.A.V.P.) guidelines for evaluating the efficacy of parasiticides for the treatment, prevention and control of flea and tick infestation on dogs and cats. Vet. Parasitol. 2007, 145, 332-344.

79. Bajer, A.; Dwużnik, D.; Tołkacz, K.; Alsarraf, M.; Mierzejewska, E.J. Comparison of the detection efficiency of haemoparasite DNA in blood and faecal samples-The way to eco-epidemiological studies. Ann. Agric. Environ. Med. 2019, 26, 538-543. [CrossRef] [PubMed]

80. Inokuma, H.; Okuda, M.; Ohno, K.; Shimoda, K.; Onishi, T. Analysis of the $18 \mathrm{~S}$ rRNA gene sequence of a Hepatozoon detected in two Japanese dogs. Vet. Parasitol. 2002, 106, 265-271. [CrossRef]

81. Kramer, V.; Randolph, M.; Hui, L.; Irwin, W.; Gutierrez, A.; Duc, J. Detection of the agents of human ehrlichioses in Ixodid ticks from California. Am. J. Trop. Med. Hyg. 1999, 60, 62-65. [CrossRef]

82. Zanet, S.; Battisti, E.; Pepe, P.; Ciuca, L.; Colombo, L.; Trisciuoglio, A.; Ferroglio, E.; Cringoli, G.; Rinaldi, L.; Maurelli, M.P. Tick-borne pathogens in Ixodidae ticks collected from privately-owned dogs in Italy: A country-wide molecular survey. BMC Vet. Res. 2020, 7, 16-46. [CrossRef] [PubMed]

83. Far, D.; Takács, N.; Gyurkovszky, M.; Solymosi, N.; Farkas, R. Ticks and tick-borne infections of dogs in two Jordanian shelters. Vector Borne Zoonotic Dis. 2021, 21, 573-578. [CrossRef] [PubMed] 